\title{
Para uma economia solidária - a partir do caso português
}

Towards a Solidarity Economy - A View Based on the Portuguese Case

Pour une économie solidaire - à partir du cas portugais

\section{Rui Namorado}

\section{OpenEdition}

\section{Journals}

Edição electrónica

URL: http://journals.openedition.org/rccs/396

DOI: $10.4000 /$ rccs.396

ISSN: $2182-7435$

\section{Editora}

Centro de Estudos Sociais da Universidade de Coimbra

\section{Edição impressa}

Data de publição: 1 Março 2009

Paginação: 65-80

ISSN: 0254-1106

\section{Refêrencia eletrónica}

Rui Namorado, "Para uma economia solidária - a partir do caso português », Revista Crítica de Ciências Sociais [Online], 84 | 2009, colocado online no dia 01 dezembro 2012, criado a 01 maio 2019 URL : http://journals.openedition.org/rccs/396 ; DOI : 10.4000/rccs.396 


\section{RUI NAMORADO}

\section{Para uma economia solidária - a partir do caso português}

Na conjuntura actual, a economia solidária deve ser encarada como uma expressão sinónima de economia social. Funciona dentro do capitalismo, embora obedeça a uma lógica distinta da lógica capitalista. Por isso, a economia solidária não deve alhear-se dos movimentos e dinâmicas sociais que reflictam qualquer tipo de resistência ou de alternatividade à lógica capitalista, principalmente em virtude das naturais sinergias que com eles podem ser suscitadas.

A economia solidária tem vocação para responder com celeridade a estímulos próximos, mas incorpora sempre uma energia futurante. O seu enraizamento territorial faz dela um dos parceiros mais críveis nos processos de desenvolvimento local, a sua identidade projecta-a universalmente.

Palavras-chave: Economia solidária, economia social, cooperação, solidariedade.

\section{Introdução}

1.1. Neste texto vai reflectir-se sobre a economia solidária, tendo como principal referência a realidade portuguesa, mas sem menosprezo pelo contexto mundial. Não se trata, contudo, de efectuar um percurso detalhado, através do conjunto das organizações do sector existentes em Portugal. Muito menos se vai dar um panorama da sua presença na Europa e no mundo. Vai apenas reflectir-se sobre alguns dos pressupostos necessários ao desenvolvimento da economia solidária e sobre as sinergias mais praticáveis e fecundas, numa perspectiva futurante, no quadro de uma conjuntura fortemente instável, fonte de uma imprevisibilidade acrescida.

A economia solidária em Portugal designa um conjunto de organizações e de práticas que está longe de estar estabilizado e de ter um âmbito bem definido. Desde logo, concorre com outras expressões para a designação de realidades idênticas ou, pelo menos, parcialmente sobreponíveis. É o que acontece, por exemplo, com expressões como economia social, terceiro sector, organizações não-lucrativas. Não é, por isso, ainda uma noção unívoca. Numa primeira abordagem, podemos dizer que a sua presença já é 
nítida, sendo, no entanto, perceptível o facto de se estar perante uma realidade ainda em construção.

Por isso, quando falamos em economia solidária em Portugal, devemos valorizar, ao lado dos seus méritos presentes, as suas virtualidades futuras. Nesta perspectiva, parece mais fecundo apontar para uma noção abrangente de economia solidária do que restringi-la a um reduto mais reduzido de práticas e de entidades, em que seja mais forte a marca solidária. Sendo assim, pelo menos no caso português, faz todo o sentido que, na conjuntura actual, se encare a economia solidária como uma expressão que no essencial é sinónima de economia social. ${ }^{1}$

Esta identificação de noções deverá encarar-se como uma sobreposição provisória que, no futuro, se poderá ou não vir a confirmar, embora a primeira hipótese se afigure no presente como a mais provável. No entanto, quando falamos hoje em economia solidária, ${ }^{2}$ estamos a sublinhar a centralidade da solidariedade como matriz de todo um sector de actividade e a

\footnotetext{
${ }^{1}$ Embora com incidência fundamental na realidade francesa, como exemplo da posição que distingue economia social de economia solidária pode ler-se Collette e Pigé (2008: 8). Uma outra perspectiva é sustentada por Roger Nanfosso (2007: 14 ss.) que fala em "economia social e/ou solidária" para depois se lhe referir simplesmente como "ESS", considerando que ela "designa o conjunto das actividades económicas que, numa economia desenvolvida ou em desenvolvimento, não tem como principal motivação o lucro. Estas actividades podem assumir formas jurídicas variadas: associações, mútuas, cooperativas" (ibid.: 18). Na entrada correspondente à "economia solidária", em L'Économie Sociale de A a Z, Jean-François Draperi começa por sublinhar que "o termo de economia solidária reenvia para duas definições distintas"; uma identifica-a "com a economia social francesa", destacando que "Esta abordagem que identifica bastante precisamente a economia social e a economia solidária em sentido amplo pode ser designada como 'a abordagem política da economia solidária' na medida em que ela é largamente partilhada pelos representantes políticos da economia solidária no mundo. Esta definição tem também um eco significativo nas Universidades latino-americanas e nas universidades europeias (por exemplo, na Alemanha)" (Alternatives Economiques, 2009: 69). A perspectiva de que a economia social é a "pioneira" e a economia solidária "uma renovação da economia social" é defendida por Prades e Costa-Prades (2005: 4 e 5). Aliás, sustentando que no essencial a economia social e a economia solidária são coincidentes e encarando até como um preciosismo a sua diferenciação, Thierry Jeantet cita Paul Singer, a quem atribui a seguinte afirmação, ao referir-se às suas próprias responsabilidades de governo no campo da economia solidária: "que não haja equívocos, estou encarregado da economia social que deve ser solidária e a verdadeira tradução do meu título é a economia social" (Jeantet, 2008: 40). Já Jean-Louis Laville e Luiz Inácio Gaiger, na entrada correspondente a Economia Solidária, integrada no Dicionário Internacional da Outra Economia, começam por afirmar que: "A economia solidária é um conceito amplamente utilizado em vários continentes, com acepções variadas que giram ao redor de ideia de solidariedade, em contraste com o individualismo utilitarista que caracteriza o comportamento económico predominante nas sociedades de mercado" (Cattani et al., 2009: 162).

2 Anne-Marie Alcolea-Bureth sublinha o carácter polissémico da noção de economia solidária, sustentado que "A economia solidária pode ser apreendida como uma nova forma de economia social, como um sector específico, como uma economia alternativa ou ainda como um novo modo de desenvolvimento local" (2004: 24).
} 
valorizar as práticas solidárias, mesmo quando são exteriores às organizações que global e inequivocamente o integram.

Neste pequeno percurso introdutório, faz todo o sentido balizar o nosso trajecto com alguns tópicos relevantes.

Em primeiro lugar, sublinhando o que atrás se disse, devemos valorizar a perspectiva que encare a economia solidária como um conjunto de organizações, sem com isso se desconsiderar, por completo, práticas sociais idênticas às dessas organizações, mas oriundas do seu exterior.

Em segundo lugar, procurando caminhar para uma ideia de conjunto da economia solidária, podemos usar para a descrever uma metáfora, a partir da qual ela poderá ser encarada como uma galáxia constituída por diversas constelações, cada uma das quais, por sua vez, é composta por astros com uma individualidade própria. Assim se induz a ideia de uma autonomia relativa de cada organização, de cada sector, articulados no seio da economia solidária, através de uma relação de interdependência, que não apaga a diferenciação e, consequentemente, a autonomia (cf. Namorado, 2004: 12 ss.).

Em terceiro lugar, há a salientar que não estamos perante uma realidade radicada num movimento social susceptível de exprimir globalmente a sua dinâmica; um movimento social cuja expressão sedimentada seja o conjunto das organizações da economia solidária. Todavia, a algumas constelações da galáxia em causa correspondem, na verdade, movimentos sociais. É, por exemplo, o caso do movimento cooperativo. ${ }^{3}$

Em quarto lugar, há que apontar, como uma das suas mais relevantes fragilidades, o facto de a grande maioria das entidades que integram a economia solidária, bem como muitos dos seus protagonistas individuais, não terem ainda interiorizado, em profundidade, uma verdadeira relação de pertença à galáxia em causa.

Em quinto lugar, para os seus protagonistas de maior rasgo, a economia solidária, para além de designar uma realidade concreta do presente, portanto já existente, projecta-se também no futuro como ambição alternativa, naturalmente integrada em qualquer horizonte que reflicta uma mudança radical da sociedade, rumo a um pós-capitalismo emancipatório e solidário. ${ }^{4}$

\footnotetext{
${ }^{3}$ No início do século XIX, quando o movimento operário nascente tinha na chamada nebulosa associativa, de início indiferenciada, a sua expressão organizada, as raízes de uma boa parte da actual economia solidária eram parte desse movimento social de vocação abrangente. Com o tempo, alguns dos seus ramos, como o cooperativo, continuaram a evoluir em simbiose com movimentos sociais correspondentes, mas outros não.

${ }^{4}$ Como exemplo de uma perspectiva que valoriza a alternatividade, pode citar-se Galaz e Prieto (2006), particularmente quando expressamente a encaram como congregadora "dos caminhos alternativos que actualmente se posicionam como resistência ao modelo económico neoliberal” (ibid.: 62). Ainda na perspectiva de uma alternatividade, mas valorizando a expressão "economia
} 
Em sexto lugar, pelo menos em Portugal, se quisermos mostrar quais as organizações que em concreto consideramos como fazendo parte da economia solidária, podemos falar de cooperativas, mutualidades, instituições particulares de solidariedade social, fundações, diversos tipos de associações, misericórdias, comunidades gestoras dos baldios, empresas sociais, empresas de inserção social, sendo certo que algumas destas categorias se sobrepõem parcialmente. ${ }^{5}$ Este perfil da economia solidária reflecte a sua identificação com a economia social, bem como a conformidade com a metáfora descritiva que a encara como uma galáxia. Nesta medida, a heterogeneidade inscreve-se no código genético da economia solidária, ficando longe a ideia de se distinguir, dentro de cada uma das constelações nela integradas, partes que se adequem a um leque normativo pré-determinado e partes que lhe sejam estranhas, ficando por isso fora dela.

1.2. Quanto ao enquadramento jurídico da economia solidária, no caso português, ele é muito facilitado, se for dada como adquirida a sinonímia entre economia solidária e economia social. Na verdade, há uma coincidência quase completa entre o âmbito da economia social, tal como é encarada pela doutrina dominante, e o sector cooperativo e social, tal como a Constituição da República Portuguesa o consagra. Pode, de facto, dizer-se que

social" e não "economia solidária", pode ler-se Draperi (2007). No mesmo sentido, mas mais expressivamente, recorde-se Paul Singer, destacado economista e principal ideólogo brasileiro da economia solidária, por cujo pelouro tem sido responsável nos governos de Lula, o qual sustenta que "A economia solidária é ou poderá ser mais do que mera resposta à incapacidade do capitalismo de integrar em sua economia todos os membros da sociedade desejosos e necessitados de trabalhar. Ela poderá ser o que em seus primórdios foi concebida para ser: uma alternativa superior ao capitalismo" (2006: 114). E mais adiante, esclarece: "A economia solidária foi concebida para ser uma alternativa superior por proporcionar às pessoas que a adoptam, enquanto produtoras, poupadoras, consumidoras, etc., uma vida melhor" (ibid.: 114). E num outro registo, mas em sentido convergente, no seu texto já referido, Laville e Gaiger concluem: "talvez mais do que dantes, precisamos de uma economia na qual o desenvolvimento social não seja uma preocupação subsidiária, relegada a mecanismos compensatórios, uma economia cuja lógica intrínseca implique e estimule a cooperação e a reciprocidade, em benefício da equidade e da justiça social." (Cattani, 2009: 168). Também o Relatório Chaves/Monzon, sobre A economia social na União Europeia, ao falar da economia solidária como algo próximo mas distinto da economia social, depois de se referir a uma concepção de economia solidária oriunda da França, menciona uma outra concepção, radicada em alguns países latino-americanos, que a encara "como uma força de transformação social portadora de um projecto de sociedade alternativa à mundialização neoliberal", ou seja, "um projecto global alternativo ao capitalismo" que se distingue das posições europeias "que consideram a economia solidária compatível com o mercado e com o Estado” (2008: 34).

${ }^{5}$ Em Portugal, tem alguma vigência no discurso corrente uma visão da economia solidária que reduz o seu âmbito às IPSS (Instituições Particulares de Solidariedade Social). Com alguma conexão com ela, embora juridicamente mais consistente, há a perspectiva que tende a ancorar a economia solidária no subsector solidário do sector cooperativo e social, constitucionalmente consagrado. 
todo o sector cooperativo e social faz parte da economia social, não sendo, contudo, verdadeiro o inverso. É que integram a economia social, mas não o sector cooperativo e social, as associações e as fundações que, tendo actividade económica, visam como objecto principal uma função que, mesmo sendo social, não é a solidariedade social. O mesmo acontece com as sociedades comerciais cuja titularidade pertença a quaisquer outras entidades do sector cooperativo e social. ${ }^{6}$

As diversas constelações da galáxia que estamos a percorrer diferem bastante entre si quanto ao grau de sistematização e de sedimentação jurídicas de cada uma delas, mas a âncora constitucional acima referida é um factor importante quer da sua robustez, quer da sua estabilidade, no plano do direito.

1.3. A partir de um outro ângulo de abordagem, vale a pena salientar que a economia solidária está geneticamente vocacionada para o curto prazo, uma vez que é ágil a responder no imediato a questões concretas, podendo, por isso, dizer-se que não há nenhum problema social que verdadeiramente lhe seja alheio. Ou seja, ela surge no contexto do capitalismo para aí agir, mas não como um dos seus instrumentos. ${ }^{7}$ Não tem que se habituar a um ambiente de mercado, porque ela própria nasceu nesse contexto, embora partes de algumas das suas constelações funcionem ao arrepio da lógica de mercado. Portanto, pode dizer-se que a economia solidária funciona dentro do capitalismo, embora obedeça a uma lógica distinta da lógica capitalista. No entanto, deve ter-se presente que nem todas as constelações que a integram reflectem no mesmo grau e da mesma maneira essa demarcação em face da lógica dominante. Globalmente, podemos dizer que a sua subalternidade no seio do capitalismo não a impede de dispor da energia alternativa necessária para poder ser concebida como parte de um horizonte pós-capitalista.

Por isso se pode afirmar metaforicamente que a economia solidária tem os pés bem assentes no presente, mas a cabeça aberta ao futuro. Assim, está naturalmente impregnada por uma ambição de alternatividade em face do capitalismo, assumindo-se, de algum modo, como um pós-capitalismo antecipado. Isto não impede que nem todas as suas constelações

\footnotetext{
${ }_{6}^{6}$ Para uma análise mais detalhada desta problemática jurídica, pode ver-se Namorado, 2006 e 2007.

7 Num sentido convergente, podem ver-se Santos e Rodriguez, quando, referindo-se a "iniciativas económicas alternativas" (onde cabe a economia solidária), sublinham que elas "têm em comum o facto de, ainda que não pretendam substituir o capitalismo de um só golpe, procurarem (com resultados díspares) tornar mais incómoda a sua reprodução e hegemonia” (2002: 29).
} 
se inscrevam com a mesma nitidez no muro branco do futuro. Do mesmo modo, nem todos os actores individuais da economia social assumem essa ambição de alternatividade, ou pelo menos não a assumem com a mesma intensidade.

A sua heterogeneidade é um elemento constitutivo da sua identidade. E é esta heterogeneidade, esta complexidade que permite que, sem reserva mental, convirjam na economia solidária não só aqueles que a assumem pela sua utilidade imediata, mas também aqueles que assumem essa utilidade em simbiose com uma ambição futurante.

Esta vocação para responder ao imediato em termos de futuro, de estar enraizada no concreto sem renunciar à utopia, torna claro que encarar a economia solidária como um simples artefacto compensatório das sequelas do capitalismo, como simples resposta conjuntural, mais ligada ao passado do que ao futuro, é amputá-la de uma parte da sua energia, é esvaziá-la do seu horizonte.

Esta plasticidade da noção de economia solidária torna-a compatível com horizontes distintos, mas não lhe retira a vocação de alternatividade necessária para a tornar uma componente potencial de um horizonte pós-capitalista. ${ }^{8}$ Ela adequa-se bem a uma concepção do processo de transformação social que valorize muito a irradiação das práticas socioeconómicas de cariz emancipatório, como um dos seus vectores mais relevantes. Deste modo, estamos perante uma perspectiva particularmente harmonizável com uma estratégia reformista, assente na sucessiva endogeneização social das mudanças que vão sendo alcançadas e num encadeamento de medidas políticas tomadas pelo Estado que aproveite e potencie essa endogeneização. ${ }^{9}$

\footnotetext{
${ }^{8}$ Para uma compreensão plena do sentido desta alternatividade, podem analisar-se com proveito as nove teses sobre as alternativas de produção, com as quais Boaventura de Sousa Santos e César Rodriguez concluem o texto "Para ampliar o cânone da produção", que introduz e enquadra o livro Produzir para Viver: os caminhos da produção não capitalista (2002: 64 ss.).

${ }^{9}$ Para ilustrar uma posição diferente, que acentua mais o grau de diferenciação da economia solidária em face do capitalismo, reduzindo-lhe normativamente o âmbito, mas atribuindo-lhe um maior potencial de ruptura anti-capitalista, pode recordar-se Paul Singer: "A economia solidária constitui um modo de produção que, ao lado de diversos outros modos de produção - o capitalismo, a pequena produção de mercadorias, a produção estatal de bens e serviços, a produção privada sem fins de lucro - compõe a formação social capitalista, que é capitalista porque o capitalismo não só é o maior dos modos de produção, mas molda a superstrutura legal e institucional de acordo com os seus valores e interesses.

Mesmo sendo hegemónico, o capitalismo não impede o desenvolvimento de outros modos de produção, porque é incapaz de inserir dentro de si toda a população economicamente activa. A economia solidária cresce em função das crises sociais que a competição cega dos capitais privados ocasiona periodicamente em cada país" (2002: 86).
} 


\section{Para o desenvolvimento da economia solidária}

Há dois pressupostos cuja verificação se considera decisiva para a irradiação da economia solidária, sem que com isso se lhes pretenda atribuir exclusividade.

2.1. O primeiro traduz-se na necessidade de uma auto-identificação clara de todas as organizações pertencentes às constelações abrangidas pela economia solidária, de modo a que se sintam e assumam como parte dela. Só assim se evitará a síndrome de isolamento, induzida pela subalternidade estrutural deste sector em contexto capitalista, suscitando-se em todas elas uma auto-confiança real, em virtude de ficarem perante a evidência de que não estão isoladas.

Ficará desse modo facilitada uma resposta jurídica susceptível de abranger toda a economia solidária e uma conceptualização mais apurada, por sua vez indutora de um maior rigor doutrinário. Tornam-se assim viáveis políticas públicas de apoio a toda a economia solidária, dotadas de uma âncora firme na realidade social, sem que se fique impedido de aplicar essas políticas apenas em constelações específicas da galáxia em causa, embora nunca se deva descurar a sua harmonização com a globalidade da economia solidária.

2.2. O segundo pressuposto situa-se no campo da avaliação do desempenho das entidades de economia solidária e dos resultados por elas obtidos. De facto, por razões fundamentalmente internas de perenidade e por razões fundamentalmente externas de legitimidade social, elas devem atribuir relevância estratégica a essa avaliação.

Dito isto, não se pode esquecer que, embora a economia solidária funcione actualmente em contexto capitalista, ela não se esgota nisso. Tem também outra lógica, bem distinta da absolutização do lucro como impulso único da actividade económica, uma lógica de cooperação e de solidariedade. E, por isso, parece claro que não tem sentido avaliar a economia solidária com base nos critérios próprios das empresas capitalistas, das empresas cujo princípio activo é o lucro. Na verdade, estes critérios obedecem no essencial ao imperativo de reprodução do tipo de sociedade actualmente dominante, com a sua hierarquia própria de vantagens e a sua escala de desigualdades. E desconsideram, por completo, a necessidade de transformação que a aproxime de uma sociedade justa, que reflicta objectivamente os interesses do conjunto dos cidadãos.

Nesta medida, a economia solidária tem pela frente a necessidade de conceber, difundir e impor critérios de avaliação do desempenho das suas organizações que incorporem a sua complexidade e a sua prospectividade. 
Daí que seja um objectivo estratégico da maior importância autonomizar e globalizar a economia solidária como objecto de estudo transdisciplinar (Alcolea-Bureth, 2004: 17 ss.).

Ao mesmo tempo, a economia solidária tem que passar a ser encarada como um tipo de prática que por si própria induz consequências positivas para a sociedade: produz bens, presta serviços, induz coesão social e criatividade pessoal. ${ }^{10}$

Em suma, a economia solidária deve pautar-se pela obediência a cânones específicos, desde que dela artificialmente se não excluam entidades que historicamente a compõem, os quais, por sua vez, devem ser espelhados em critérios de avaliação específicos.

\section{A economia solidária como pólo de atracção}

3.1. Compreende-se que, para a sua própria robustez, equilíbrio e perenidade, a economia solidária não deva abdicar de uma auto-reflexão doutrinária e prospectiva que dê consistência ao facto de ela se assumir historicamente como futuro. Também por isso, todas as entidades que a integram devem dispor de uma informação sistemática sobre o que de relevante acontece no âmbito desta galáxia. Tanto mais que a sua subalternidade implica que um dos factores mais actuantes do seu apoucamento seja, precisamente, o esbatimento da imagem global do sector como espaço de pertença, no qual se possam sentir integradas todas as entidades da economia solidária, no quadro de uma auto-representação que valorize esse envolvimento.

Do mesmo modo se compreende, à luz do que se acaba de dizer, que a economia solidária não deva alhear-se dos movimentos e dinâmicas sociais que reflictam qualquer tipo de resistência ou de alternatividade à lógica capitalista, principalmente em virtude das naturais sinergias que com eles podem ser suscitadas. Essa proximidade não deve pôr em causa a autonomia da economia solidária, o que não invalida a utilidade de um fluxo continuado de informações nos dois sentidos e a realização de iniciativas conjuntas.

3.2. Na sequência do que se acaba de dizer, vamos agora referir, apenas a título de exemplo, alguns dos fenómenos sociais objectivamente mais vocacionados para se envolverem nessas sinergias. Situam-se em níveis e planos distintos, sendo também diversificados os tipos de conexão que os relacio-

\footnotetext{
${ }^{10}$ Como exemplo de uma perspectiva que vai mais longe na consideração autónoma da economia solidária, pode referir-se a posição de Paul Singer, para quem "A economia solidária é outro modo de produção, cujos princípios básicos são a propriedade colectiva ou associada do capital e o direito à liberdade individual (...). O resultado natural é a solidariedade e a igualdade, cuja reprodução, no entanto, exige mecanismos estatais de redistribuição solidária da renda” (2006: 10).
} 
nam com a economia solidária. No entanto, em conjunto, correspondem a um amplo leque de dinâmicas sociais, cuja consideração global dá uma imagem sugestiva do contexto diversificado que mais proximamente envolve a economia solidária.

\subsubsection{Desenvolvimento local}

Os processos de desenvolvimento local precisam da economia solidária para ganharem consistência e humanidade; e a economia solidária tem nos processos de desenvolvimento local um dos contextos mais potenciadores das suas virtualidades quer imediatas, quer estratégicas. De facto, o desenvolvimento local impregnado pela economia solidária pode deixar de ser apenas um processo de requalificação de regiões deprimidas, para passar a ser também um ponto de partida consistente de uma verdadeira renovação social. ${ }^{11}$

Duas outras considerações são aqui relevantes. Em primeiro lugar, a fiabilidade das organizações da economia solidária como parceiros nos processos de desenvolvimento local resulta da sua própria natureza, do seu enraizamento nas pessoas, que torna objectivamente impossíveis (ou, pelo menos, muito difíceis) os processos de deslocalização. Em segundo lugar, o enraizamento local das entidades da economia solidária e as suas tradições internacionalistas incorporam em si próprias a simbiose virtuosa entre o local e global.

\subsubsection{A protecção do ambiente}

As visões do mundo e da vida impregnadas pela valorização da ecologia têm na protecção ambiental um dos seus elementos básicos. E as regras de salvaguarda do ambiente, por ela implicadas, são, no seu sentido mais fundo, um limite ao funcionamento sem peias da lógica do lucro (cf. Carvalho, 1997: 29). Reflectem, por isso, naturalmente, uma visível preocupação pelo que podem sofrer as gerações futuras com a degradação ambiental do planeta.

Em paralelo, o humanismo da economia solidária não permite que ela se desinteresse dos efeitos que possa produzir na qualidade de vida dessas

\footnotetext{
${ }^{11}$ Como exemplo de uma perspectiva que sustenta a ideia de uma sinergia mais funda, estrutural e prospectiva, entre a economia solidária e o desenvolvimento local, pode ler-se a colectânea editada sob a direcção de Taoufik Daghri e Hassan Zaoual, Économie Solidaire et Développement Local (2007). Na mesma linha teórica, Anne-Marie Alcolea-Bureth utiliza o conceito de "economia solidária territorial". Este conceito suscita, aliás, uma nova perspectiva quanto ao desenvolvimento local, ajudando a compreender a dinâmica das organizações da economia solidária, tendo em conta não apenas o mercado e o Estado, mas também a sua relação "com o seu próprio modo de organização e com o seu próprio modo de funcionamento" (2004:339), territorialmente considerados.
} 
gerações. Por isso, a economia solidária tem uma lógica e um tipo de funcionamento que se harmonizam facilmente com o respeito pela protecção ambiental. Aliás, algumas das constelações e das entidades que pertencem à galáxia solidária assumem a salvaguarda ambiental como um dos seus objectivos centrais ou até como a sua própria razão de ser. ${ }^{12}$

\subsubsection{A defesa dos direitos dos consumidores}

A necessidade de uma consideração jurídica autónoma dos consumidores conducente a uma protecção adequada dos respectivos direitos evidencia a insuficiência dos mecanismos do mercado e do direito civil comum como garantes suficientes dos interesses dos consumidores. ${ }^{13}$

Por seu lado, as entidades de economia solidária, relativamente às quais se pode colocar a questão da protecção dos consumidores que com elas se relacionem, têm inscrita no cerne da sua identidade a importância desses direitos. No respectivo código genético, tem um lugar decisivo a salvaguarda dos interesses dos respectivos consumidores a quem se destinam os bens que facultam ou os serviços que prestam. Aliás, há entidades da economia solidária que têm a sua razão de ser na afirmação de estratégias específicas de defesa dos consumidores, como é o caso das cooperativas de consumo e das associações de defesa dos consumidores. E a cooperação de consumo, nos primórdios do século passado, chegou a ser o eixo estruturante da proposta de Charles Gide de uma República Cooperativa, caracterizada pela centralidade nela atribuída aos consumidores. ${ }^{14}$

\subsubsection{A humanização das relações de trabalho}

O respeito pela condição humana dos trabalhadores, que deve impregnar as relações de trabalho vividas nas organizações da economia solidária, é um índice da fidelidade destas organizações ao essencial da sua identidade. Nessa medida, estas entidades devem assumir uma profunda sintonia com a lógica mais estruturante do direito do trabalho.

$\mathrm{Na}$ verdade, a própria razão de ser de um espaço jurídico diferenciado, como é o direito do trabalho, está no reconhecimento de que as relações laborais não podem ser reguladas como se fossem simples fruto de um contrato como qualquer outro. De facto, a fragilidade da posição do traba-

\footnotetext{
${ }^{12}$ É ostensiva a enorme difusão do movimento associativo suscitado pela temática ecológico-ambiental.

${ }_{13}$ Para um esclarecimento mais aprofundado desta problemática pode ler-se Direito do Consumo, de Carlos Ferreira de Almeida (2005: 15 ss.).

${ }^{14}$ Para uma compreensão plena das posições de Charles Gide, pode ver-se o seu O Programa Cooperatista (1937); e ainda Diva Pinho (1966: 54 ss.).
} 
lhador nessa relação jurídica, perante a prevalência de uma lógica de lucro que caracteriza o funcionamento das empresas capitalistas, tornou necessária a imposição de limites a essa lógica. ${ }^{15}$ Ora, a economia solidária não pode, sob pena de incongruência ética e de quebra da sua coerência funcional, consentir na existência de espaços de insolidariedade no seu próprio seio. Sob pena de descaracterização identitária, no seu código genético há-de estar inscrita a valorização do trabalho e, naturalmente, o consequente respeito pelos direitos dos trabalhadores.

Nessa medida, pode dizer-se que a economia solidária partilha com o direito do trabalho todo o leque de valores que sustentam a humanização do trabalho, o que lhe permite um espaço de relacionamento positivo com os sindicatos, na procura de novas sinergias apontadas para novos horizontes. Horizontes que consubstanciem uma mudança do próprio tipo de sociedade, ou seja, horizontes pós-capitalistas.

\subsubsection{Convergência numa sociedade educativa}

Qualquer horizonte alternativo, verdadeiramente libertador e solidário, não pode deixar de assumir como um dos seus eixos estruturantes o binómio ensinar-e-aprender, como atmosfera permanente da condição humana. Por isso, a educação ao longo da vida ${ }^{16}$ entendida na sua amplitude verdadeira, é um dos aspectos irremovíveis do quotidiano de qualquer sociedade futura que mereça ser sonhada. Educação ao longo da vida que pressupõe, obviamente, uma partilha justa do trabalho, do lazer e dos rendimentos, ausentes nas sociedades de exploração.

Há, pois, uma partilha de horizonte entre a economia solidária e a educação, mas, para além disso, são muitas as sinergias parcelares que entre ambas se vão tecendo desde já.

De facto, pelo menos uma das constelações da economia solidária, a das cooperativas, tem o princípio da educação como um dos seus eixos identitários (cf. Namorado, 2005: 33 ss.). E para além delas, noutras áreas da economia solidária há um forte envolvimento em tarefas educativas.

Economia solidária e educação são duas dinâmicas e dois espaços que potenciam mutuamente as suas virtualidades, quando se articulam e inter-

\footnotetext{
${ }^{15}$ Sobre o essencial desta problemática, pode ler-se a síntese brilhante de Orlando de Carvalho, 1990.

${ }^{16}$ No Relatório elaborado para a UNESCO, pela Comissão internacional sobre a educação para o século XXI, presidida por Jacques Delors, intitulado L'Éducation - un trésor est caché dedans, pode ler-se: "O conceito de educação ao longo da vida surge assim como uma das chaves de entrada no século XXI" (Unesco, 1996: 17). E mais adiante prossegue: "A Comissão evocou esta outra utopia: a sociedade educativa fundada na aquisição, actualização e utilização dos conhecimentos" (ibid.: 19).
} 
penetram. Dificilmente a educação ao longo da vida pode impregnar o tecido social como verdadeira seiva sem recorrer às organizações que constituem a galáxia da economia solidária. Dificilmente a economia solidária ganhará amplitude para poder aspirar à superação da sua subalternidade, sem uma educação ao longo da vida suficientemente disseminada para nos aproximar de uma verdadeira sociedade do conhecimento.

E é neste contexto que se deve valorizar a afirmação da economia solidária, das organizações e das práticas de economia solidária, como objecto de investigação e de estudo verdadeiramente autónomo. Simetricamente, faz todo o sentido que todas as instituições que dentro da galáxia da economia solidária se ocupam da educação em todas as suas vertentes se congreguem para se diferenciarem como província autónoma no seio das instituições educativas.

\subsubsection{Pela cultura como um contexto emancipatório}

A subalternidade da economia solidária no contexto capitalista reforça a necessidade de os seus actores terem uma visão crítica da sociedade, de modo a que a não estejam condenados a vê-la apenas através da perspectiva ideológica dominante. Ora, uma das condições necessárias para a solidez de uma visão crítica da sociedade é a profundidade do seu enraizamento cultural.

A cultura enquanto reflexo de um conhecimento humanizante, factor de libertação individual e colectivo, agilização do pensamento como consciência social crítica, é um contexto indispensável para a viabilidade de um processo continuado de afirmação da economia solidária. De facto, um contexto cultural vivo e diversificado é indispensável para que as componentes da economia solidária amadureçam e interajam entre si.

Em contrapartida, a galáxia da economia solidária pode afirmar-se como um dos eixos estruturantes de uma nova cultura que antecipe e prepare a emergência de uma sociedade outra. $\mathrm{Na}$ verdade, são muitos os agentes culturais que actuam no quadro de entidades integradas na galáxia em causa.

3.3. Estes e outros vectores e aspectos do desenvolvimento social podem polarizar-se em torno da economia solidária, enquanto estruturas e práticas de reconhecida utilidade social (cf. Chaves e Monzon, 2008: 30), a qual tende a ser instituída como um dos eixos da economia solidária. É como se a utilidade social de organizações e realizações fosse o verdadeiro tecido conjuntivo desse conjunto.

Mas, além de a economia solidária ser um pólo agregador de práticas e fenómenos sociais que com ela convergem, pode ainda oferecer-se como o 
seu horizonte, o sentido da sua evolução como sinal estratégico de todas estas dinâmicas e movimentos sociais.

Por exemplo, ganha relevo como aspecto desse horizonte e elemento central da modernização social a superação do desemprego, através da repartição do trabalho, do ócio e dos rendimentos, ao longo da vida. Superação essa, naturalmente conjugada com a educação ao longo da vida, que por sua vez se revela determinante para a possibilidade de um lazer criativo, sem cuja generalização a repartição do trabalho nunca atingirá todo o seu potencial libertador.

$\mathrm{Na}$ verdade, as estruturas da economia solidária são suficientemente flexíveis, diversificadas e próximas das pessoas, para poderem materializar a ideia de uma ecologia social de matriz solidária e emancipatória.

\section{O futuro da economia solidária}

4.1. A economia solidária afirma-se e desenvolve-se numa simbiose virtuosa entre o individual e o colectivo, o concreto e a utopia, o local e o universal, o imediato e o longo prazo. Na verdade, ela envolve a congregação de criatividades e generosidades pessoais que se potenciam pela sua disponibilidade cooperativa. Tem vocação para responder com celeridade a estímulos próximos, mas incorpora sempre, em maior ou menor medida, uma energia futurante. O seu enraizamento territorial faz dela um dos parceiros mais críveis nos processos de desenvolvimento local, mas a sua identidade socialmente radicada projecta-a planetariamente. A sua plasticidade organizativa permite-lhe ser ágil e rápida perante os problemas que enfrenta, mas insere-se com naturalidade nas grandes narrativas históricas. Por isso, envolve práticas e organizações que não só valem por si próprias, como exercícios de uma virtude socialmente qualificante, mas também pelos resultados concretos que permitem alcançar.

4.2. Se rompermos a neblina de auto-sustentação ideológica, gerada pelos pólos mediáticos dominantes no mundo actual, veremos com nitidez que as sociedades do presente correm o risco de bloqueamento, tornando-se sociedades sem futuro. Sociedades sem futuro, por inibição de tornarem evidente o futuro que elas próprias receiam, na constância do sistema capitalista. De facto, é hoje uma evidência crescente que a desumanização economicista da sociedade põe em causa a habitabilidade do planeta e desse modo a própria sobrevivência da espécie.

Não é realista esperar que esta situação seja superável sem transformações radicais, sem uma verdadeira mutação civilizacional, o que exige, na senda de Edgar Morin, "uma política de civilização" que nas suas palavras suscite 
"um outro modo de vida", "um outro modo de produzir" e "um novo modo de consumir" (Morin e Naïr, 1997: 121).

De facto, se o capitalismo não é o fim da história, deve poder conceber-se o-depois-dele como um pós-capitalismo. Todavia, se o capitalismo conseguir apodrecer o seu próprio fim, pode bem acontecer que em vez de ser o fim da história seja o fim da vida da terra. E mesmo antes de se atingir esse limiar ecológico de catástrofe, na constância do capitalismo, pode bem acontecer que se acelerem dramaticamente as pulsões dissipativas que já se multiplicam na actualidade, o que pode bem conduzir à implosão social de países e até de continentes. Por isso, acelerar o passo rumo a um pós-capitalismo é também diminuir o risco dessa implosão.

$\mathrm{E}$, se caminhar rumo a um pós-capitalismo implica necessariamente algum protagonismo público, alguma pilotagem a partir do Estado, não se deve ignorar que, principalmente, estamos perante um complexo processo de gradual endogeneização social das mudanças que no fundamental se há-de desenvolver por irradiação. Se assim for, um processo que dominantemente se desenvolva por irradiação há-de basear-se, em larga medida, naquilo que, no quadro do capitalismo, resiste ou escapa à sua lógica. Por isso, a economia solidária não pode deixar de ser um elemento central desse processo. ${ }^{17}$

$\mathrm{E}$, sendo o pós-capitalismo mais um horizonte partilhado do que um modelo fechado, comporta a possibilidade de ir sendo aperfeiçoado e detalhado, à medida que dele nos vamos aproximando. Acontece que a economia solidária convive bem com a incompletude e a perfectibilidade, porque incorpora essas características no mais fundo de si própria. ${ }^{18}$

4.3. Assim, numa conclusão aberta e provisória, é legítimo dizer-se que a economia solidária pode impregnar uma tenaz virtuosa impulsionadora de uma necessária mutação civilizacional. De facto, ela é um elemento importante nos processos de desenvolvimento local, e está bem posicionada para se tornar num agente relevante de uma globalização pós-capitalista, emancipatória e solidária ${ }^{19}$ que verdadeiramente se harmonize com uma ecologia humana.

\footnotetext{
${ }^{17}$ Em convergência com esta perspectiva, Jean-Louis Laville salientou: "Não é, por outro lado, anódino que a inscrição da economia solidária nos fóruns sociais mundiais tenha coincidido com a passagem do anti-mundialismo para o altermundialismo. Com efeito, a economia solidária entra em consonância com um movimento que já não se limita a protestar, mas articula reivindicações e propostas" (2007: 282).

${ }^{18} \mathrm{Na}$ colectânea de textos Économie Solidaire: propositions pour un autre modele de développement, coordenada por M. Boulianne, H. Ortiz e L. Fraisse, no quadro da posição que encara "a economia solidária como fundamento de uma economia alternativa", pode ler-se: "O cenário pós-capitalista reinscreve os empreendedores da economia solidária como precursores de modos de produção e de consumo alternativos à globalização neoliberal" (2005: 45).

19 Boaventura de Sousa Santos e César Rodriguez iniciam assim a sua "Introdução: para ampliar
} 


\section{Referências bibliográficas}

Alcolea-Bureth, Anne-Marie (2004), Pratiques et théories de l'économie solidaire: Un essai de conceptualisation. Paris: L'Harmattan.

Almeida, Carlos Ferreira de (2005), Direito do consumo. Coimbra: Almedina.

Alternatives Economiques (2009), L'Économie Sociale de A à Z. Paris: Alternatives Économiques.

Boulianne, Manon; Ortiz, Humberto; Fraisse, Laurent (orgs.) (2005), Economie solidaire: Propositions pour un autre modèle de développement. Paris: Editions Charles Léopold Mayer.

Carvalho, Orlando de (1990), "Empresa e Direito do Trabalho", in Temas de Direito do Trabalho. Coimbra: Coimbra Editora.

Carvalho, Orlando de (1997), "Empresa e lógica empresarial”, in Estudos em Homenagem ao Prof. Doutor A. Ferrer-Correia. Coimbra: Boletim da Faculdade de Direito.

Cattani, A. D.; Laville, J.-L.; Gaiger, L. I.; Hespanha, P. (orgs.) (2009), Dicionário internacional da outra economia. Coimbra: Almedina/CES.

Chaves Ávila, Rafael; Monzón Campos, José Luis (2008), La economía social en la Unión Europea. Bruxelles: Comité Económico y Social Europeo.

Collette, Christine; Pigé, Benoît (2008), Economie sociale et solidaire: [gouvernance et contrôle]. Paris: Dunod.

Daghri, Taoufik; Zaoual, Hassan (orgs.) (2007), Economie solidaire et développement local: Vers une démocratie de proximité. Paris: L'Harmattan.

Draperi, Jean-François (2007), Comprendre l'économie sociale: fondements et enjeux. Paris: Dunod.

Galaz, Caterine; Prieto, Rodrigo (2006), Economía solidaria: De la obsesión por el lucro a la redistribución con equidad. Barcelona: Icaria Editorial.

Gide, Charles (1937), O Programa Cooperatista. Lisboa: Seara Nova.

Jeantet, Thierry (2008), L'économie sociale: Une alternative au capitalisme. Paris: Economica. Laville, Jean-Louis (org.) (2007), L'économie solidaire: Une perspective international (Nouv. éd. rev. et actual.). Paris: Hachette Littératures.

Morin, Edgar; Naïr, Samir (1997), Une politique de civilisation. Paris: Arléa.

Namorado, Rui (2004), A economia social: Uma constelação de esperanças. Coimbra: CES-FEUC.

Namorado, Rui (2005), Cooperatividade e direito cooperativo: Estudos e pareceres. Coimbra: Almedina.

o cânone da produção": "Como demonstra a consolidação recente de numerosos movimentos e organizações de todo o mundo que lutam por uma globalização contra-hegemónica, os vários séculos de predomínio do capitalismo não conseguiram diminuir a indignação e a resistência efectiva aos valores e às práticas que constituem o núcleo central do capitalismo, enquanto sistema económico e forma de civilização" (2002: 23). 
Namorado, Rui (2006), Os quadros jurídicos da economia social: Uma introdução ao caso português. Coimbra: CES-FEUC.

Namorado, Rui (2007), Renovar os quadros jurídicos da economia social?. Coimbra: CES-FEUC.

Nanfosso, Roger A. Tsafack (org.) (2007), L'économie solidaire dans les pays en développement. Paris: L'Harmattan.

Pinho, Diva Benevides (1966), A Doutrina Cooperativa nos Regimes Capitalista e Socialista. São Paulo: Livraria Pioneira Editora.

Prades, Jacques; Costa-Prades, Bernadette (2005), L'économie solidaire: Prendre sa vie en main. Toulouse: Editions Milan.

Santos, Boaventura de Sousa; Rodríguez, César (orgs.) (2002), "Introdução: Para ampliar o cânone da produção", in B. S. Santos (org.), Produzir para viver: Os caminhos da produção não capitalista. Rio de Janeiro: Civilização Brasileira.

Singer, Paul (2002), “A recente ressurreição da economia solidária no Brasil”, in B. S. Santos (org.), Produzir para viver: os caminhos da produção não capitalista. Rio de Janeiro: Civilização Brasileira.

Singer, Paul (2006), Introdução à economia solidária. São Paulo: Editora Fundação Perseu Abramo.

Unesco (1996), L'Éducation - un trésor est caché dedans. Paris: Odile Jacob. 